\title{
時間と空間認識の統合を目指して 一高校地理歴史科教員からの提言一
}

小林正人

\section{1. はじめに}

世界史未履修問題は、実態としては高等学校 未履修問題としてとらえた方が妥当である。 2006年未履修問題は世界史で始まったが、その 後の文部科学省の 2006 年12月13日付調査結果 ${ }^{1)}$ では世界史以外にも多くの教科で未履修問題が 発生し、総未履修件数は 1,095 件、その中で最も 多かったのが地理歴史科で未履修件数の $42 \%$ を 占め、次いで情報科 $22.6 \%$ 、公民科 $6.9 \%$ 、理科 6.8\%の順になっている。学校数では高校全体の 1割を超える663校に上っている。

これは学校完全 5 日制による週当たり授業時数 の削減と総合的な学習の時間や情報などの新設 科目の導入で、各校の教育課程に従来位置づけ られていた科目数及び単位数を位置づけること ができなくなり、一部の学校では何らかの理由 (多くは大学受験対策)で必履修になっている科 目を行わずに、その時間を別の科目に充当して しまったことによる。つまり高等学校未履修問 題は、日本の教育制度と大学受験競争がもたら した構造的な問題なのである。

\section{2. 世界史末履修問題で何が見えたか}

ところで地理歴史科とはどのような教科なので あろうか。高等学校学習指導要領によれば「我が 国及び世界の形成の歴史的過程と生活 - 文化の地 域的特色についての理解と認識を深め、国際社会
に主体的に生きる民主的、平和的な国家・社会の 一員として必要な自覚と資質を養う」という独自 の目標があり、科目は世界史A $\cdot$ B、日本史A · $\mathrm{B}$ 、地理 $\mathrm{A} \cdot \mathrm{B} て ゙$ 構成され、科目相互の関連性を 重視しなければならないことになっている。しか し地理歴史科で未履修問題が発生した学校数は 460校であり、そのうち「世界史」の未履修のみ 存在する学校 110 校、生徒の選択の結果、生徒の 中に、「世界史」の未履修者、「日本史叉は地理」 の未履修者が 1 つの学校に同時に存在する学校は 256校である。つまり世界史未履修問題の発生 は、言い換えれば、世界史を含めた地理歴史科教 育の重要性が理解されずに無視されたということ でもある。本来地理歴史科教育は、世界史・日本 史・地理すべてを学習して得ることのできる空間 認識と時間認識及びそれによってもたらされる地 理歴史の総合的思考力の育成にこそ主眼が置かれ るべきである。しかし地理歴史科は創設の時から 国際化への対応のため世界史が必履修、日本史と 地理は選択履修であった。もし選択履修で日本史 を選択した場合、地理は選択しなくてよいことに なり、空間認識は形成されないことになる。地理 歴史科は発足当初からある意味の構造的な未熟性 を内包していたのである。

従って、世界史未履修問題は日本の教育制度 と受験競争がもたらした構造的な問題の上に、 地理歴史科教育の未熟性が重なった複雑な構造 をなしているのである。 


\section{3. 地歴融合科目、 歴史基礎の創設の問題点}

平成 20 年 6 月 7 日 (土) 東京大学教養学部で公 開シンポジウム「高校教育における時間と空間 認識の統合一世界史未履修問題をどう解決す るのか」が開催された。第2部解決策の提案で は、世界史の立場から東京大学名誉教授桜井由 躬雄、日本史の立場から神戸大学名誉教授高橋 昌明の 2 人がともに、地歴融合ではなく歴史基礎 を提案された。筆者は幸いにもコメントをする 機会を得た。その概要は以下である。

第一に、全国地理教育学会地理歴史科教育研究 小委員会の高等学校地理教員への「地理教育と歴 史教育の連携についての意識調查」(資料1)の結 果によれば、多くの地理教員は地歴の関連性は必 要であるが、地歷融合科目の創設には賛成してい ないことが明らかになった。また筆者の勤務校の 3 年生への「地歴融合科目」新設に関するアンケー 卜調査結果 (資料2)では、地歴融合科目の創設に 肯定的な回答よりも否定的な回答が上回った。生 徒の自由意見を分析すると、肯定的な立場は、総 合的な視点が身につくという意見と、地歷融合科 目だけを取ればよいので楽であるという意見が大 半を占めた。否定的な意見は、複雑かつ膨大な内 容で自分が落ちこぼれてしまうことへの不安や地 歴融合科目の創設の必要性を感じられないとの意 見が大半を占めている。この生徒の主な自由意見 は、肯定的意見・否定的意見ともに傾聴に值する

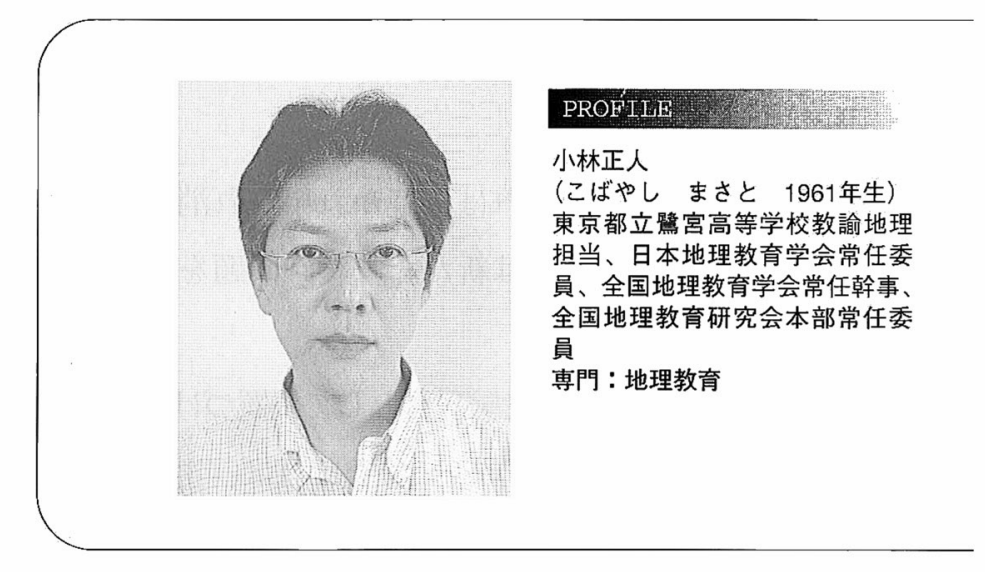

資料 1 地理教育と歴史教育の連携についての 意識調査結果について

実施者 全国地理教育学会地理歴史科教育研究小委員会

実施日 2008年2月下旬 3月上旬

対 象 千葉県公・私立高等学校196校

回答数 89 校

回収率 $45.4 \%$

(1)地理と歴史の内容を相互に関連させる学習の重要性について

\begin{tabular}{lrr}
\hline & 回答数 & 割合 \\
\hline 非常に思う & 43 & $48 \%$ \\
まあまあ思う & 33 & $37 \%$ \\
じちらともいえない & 7 & $8 \%$ \\
あまり思わない & 2 & $2 \%$ \\
全く思わない & 2 & $2 \%$ \\
無回答 & 2 & $2 \%$ \\
\hline
\end{tabular}

(2)地歴の関連方法について

\begin{tabular}{lrr}
\hline & 回答数 & 割合 \\
\hline 新科目を作り、必修化 & 7 & $8 \%$ \\
新科目を作り、選択必修化 & 4 & $5 \%$ \\
融合単元の設定 & 21 & $23 \%$ \\
科目間で関連性を意識する & 54 & $61 \%$ \\
関連した指導は不要 & 1 & $1 \%$ \\
無回答 & 2 & $2 \%$ \\
\hline
\end{tabular}

(3)地歴間の議論の充実度

\begin{tabular}{lrr}
\hline & 回答数 & 割合 \\
\hline 十分にある & 1 & $1 \%$ \\
まあまあある & 15 & $17 \%$ \\
あまりない & 45 & $51 \%$ \\
全くない & 26 & $29 \%$ \\
その他 & 2 & $2 \%$ \\
\hline
\end{tabular}

と考光られる。

第二に、提案のあった歴史基礎が受験科目に なり得るのかどうかという点である。もし受験 
科目にならなければ、遅かれ早かれ消光ゆく運 命であり、それは新たな未履修問題を生み出す ことになる。

第三に、もし受験科目として位置づけられたと しても、歴史基礎を2単位とすれば、学習内容は 通史学習で構成することは極めて困難であり、主 題学習を中心にして歴史的思考力を高める構成に ならざるを得ない。筆者はその内容に賛成である が、これは日本の高校歴史教育の転換となる。通

\section{資料2「地歴融合科目」新設に関するアンケート結果}

実施日 2008年5月下旬

対 象 東京都立䉆宮高等学校3年生

在籍数 262 名

回答数 243 名

\section{○地歴融合科目の新設について}

\begin{tabular}{lrr}
\hline & 回答数 & 割合 \\
\hline (1)大いに評価できる & 9 & $4 \%$ \\
(2)評価できる & 39 & $16 \%$ \\
(3)どちらとも言えない & 134 & $55 \%$ \\
(4)あまり評価できない & 24 & $10 \%$ \\
(5)評価できない & 37 & $15 \%$ \\
\hline
\end{tabular}

\section{主な自由意見}

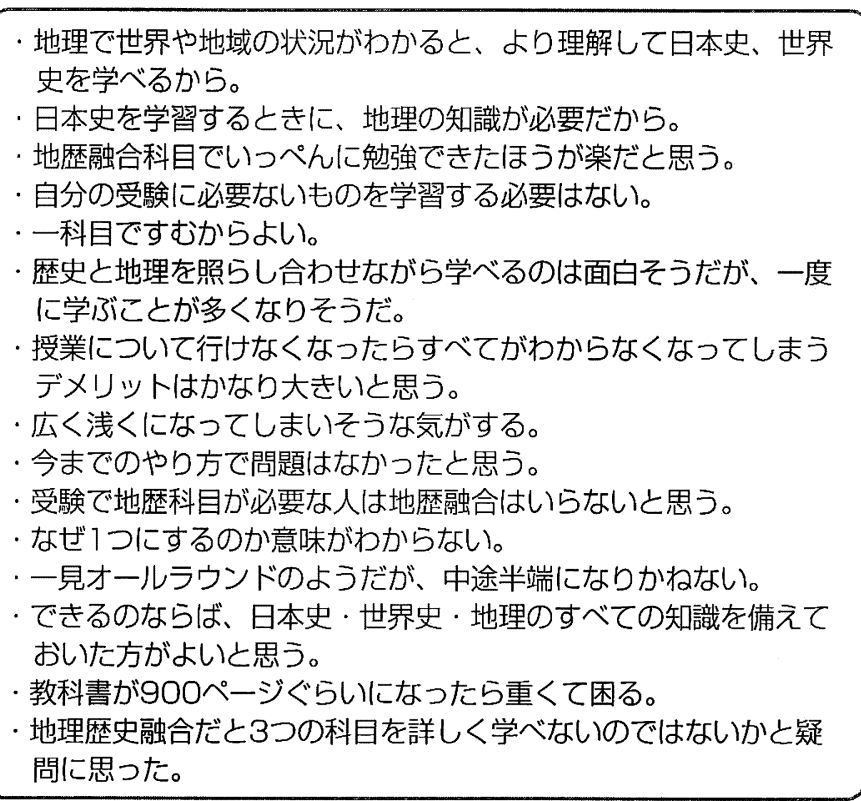

史学習になれた学校現場で歴史基礎の趣旨が理解 されてそのような学習が適切に行われるために は、相当な困難を伴うことは明白である。

第四に、主題学習が中心になるならば、大学 入試問題で、適切な問題が作問されるのか疑問 である。一部の大学では知識よりも歴史的思考 力を試す問題が出題されるかもしれない。しか し大多数の大学で出題できるのかは疑問である。 もし知識を問う問題に終始すれば、学校現場は 通史学習に回帰し、歴史基礎は見向きもされず 世界史と日本史に収斂されてしまうであろう。 歴史基礎を創設するならば、大学入試問題の改 善を同時並行で行わなければならない。言い換 えれば、歴史基礎は大学入試問題の改善があっ て初めて成立するのである。

第五に、持続可能な開発が叫ばれている現代 において、地球環境を維持するためにどのよう に生きるのか厳しく問われている時代である。 地理歴史科も過去や他地域を学習するだけでは なく、その学習成果に基づいて今をどのように 生きるかという公民的資質の有成に関与しなけ ればならない時期にきていると筆者は考える。 従って公民的資質には事実認識と、価值判断 . 意思決定の両方が必要であるから、地理歴史科 と公民科の枠組みを再度見直し、この2教科を合 体して新教科を設立（あるいは社会科の復活） し、融合科目もそのような枠組みで考えるべき である。しかし新教科設立が難しいのであれば、 世界史、日本史、地理の科目の枠組みは残し、 それぞれの科目の中に地歴融合単元を設置する 
案を支持した。

\section{4. まとめにかえて}

日本学術会議「高校地理歴史科教育に関する分 科会」は、さまざまな討議を経て新科目を創設す る方向で未履修問題の解決を模索している。しか し、世界史未履修問題は日本の教育制度の構造的 問題であること、地理歴史科教育が未熟であるこ と、歴史基礎は新たな未履修問題を生み出しかね ないこと、歴史基礎の適切な実施には相当な困難 を伴うこと、歴史基礎は大学入試問題の改善があ って初めて成立すること等の問題点を指摘した。 従って、現状での新科目の設置は多くの問題 点を抱えていることから、筆者は否定的である。 現状では、地理歴史科と公民科の合体も難しい ことから、世界史の必履修をやめ、世界史、日 本史、地理から、2つの科目を選んで必ず履修す る、選択必履修を第一に考光るべきであること を提言したい。

ところで、筆者は今や高校生にとって、歴史 学習は暗記という大変な苦労を伴う苦しい科目 であり、できれば避けたい科目と感じている生 徒が多くなっているように感じる。それはコン ピュータやインターネットの普及で、暗記しな くてもパソコンで検索すればすぐに情報を引き 出せることと無関係ではない。この変化は地理 歴史科にとって実は深刻な問題で、今地理歴史 科離れという危機的状況が深く静かに進行して いるといえるのではあるまいか。大学受験とい
う安住の地を離れ、地理や歴史を学ぶ意味を理 解でき、楽しさを味わえる魅力的な学習を構築 しなければ、地理歴史科は限りなく衰退する可 能性をもっている。それは国民教養の著しい低 下につながる。

この状況を抜本的に解决するためには、地理学 と歴史学と教育学の専門家によって「時間と空間 認識の統合」をキーワードに、地理歴史科教育の 目的、学習内容、学習方法、各科目の学習の順序 性等を研究し発展させることを筆者は切望する。

国民の教養として地理歴史科教育の根本にかか わる部分はどのようにあるべきか。分科会にはそ のような検討を期待したい。

\footnotetext{
参考文献

1) 文部科学省(2006) 高等学校等の未履修開始年度等 について

http://www.mext.go.jp/b_menu/houdou/18/12/06121404/001. $\mathrm{htm}$ 2008/9/23検索
} 